\title{
On Application of Computer Information System in Coal Production Safety Management
}

\author{
Lin Zhou \\ Chongqing Business Vocational College, Chongqing, 401331, China
}

Keywords: computer; information system; coal production safety management

\begin{abstract}
With computer information system, coal production safety management can develop into an integral system. The computer is used to analyze, compute, control and carry out emergency processing so that coal production safety can gain technical guarantee. However, in terms of the combination degree of coal mining industry with production safety and information technology, there are many shortcomings. This paper summarizes computer application situations of coal enterprises analyzes current situation of computer information system applied in coal production safety management, discusses specific application of computer information system in coal production safety management and proposes countermeasures to further apply computer information system in coal production safety management.
\end{abstract}

\section{Introduction}

Coal resources in China are very rich. China is the largest coal producing country globally. On the whole, death rate per million tons of Chinese coals is on the decrease and presents a good situation. But compared with western developed coal producing countries, China still has a large gap in coal safety management field. In particular, the frequency of serious gas explosion accidents is much higher than that of other countries. So, main problems of coal production safety must be recognized so as to practically solve coal mine safety management problems. On this account, coal mine safety management can better develop to benefit and scientization only when traditional manual operation is changed to computer application in hidden danger collection, retrieval, cataloging, statistics and development tendency analysis.

\section{Computer application status of coal enterprises}

Among some large or super-large coal enterprises, safety management with computer has reached a high level. However, on the whole, in most coal enterprises, computer application level is not high enough, which is mainly reflected in the following aspects. 1) In terms of the application form, computer application is independent. The work content is very single. In most cases, computer application situation still belongs to many different departments in an enterprise. 2) As for the application content, a large number of computer systems still simple handle production safety monitoring information and production safety information. For example, information display, inquiry, statistics, print and storage are just implemented for information gathered. As a result, information resources are single and isolated so that information blockage appears among each department and between superiors and subordinates. This leads to serious waste of information resources. Besides, large quantities of meaningless repeated work are done. Meanwhile, since computer information resources are not processed or just simply processed, the level of safety management with computer is not high enough, and safety prediction and assistant decision making cannot be realized.

\section{Current situation of application of computer information system in production safety management}

Coal production safety information management system mainly refers to an information management system based on computer networking technology and expert system. According to 
computer information system principles, gas monitoring system, mine ventilation network monitoring system and mine pressure monitoring system can be organically combined to fulfill sharing of computer information resources so as to provide corresponding basis for coal production safety decision-making and improve application level of computer information system in coal production safety management. The analysis of current situation of application of computer information system in coal production safety management is as follows. 1) Coal equipment lags behind. In China, most coal mines are in the provinces with complex terrain. Due to unclear geological conditions, great production safety accidents may easily happen. Since the depth of geological exploitation continuously increases, the risks of ground collapse also become increasingly large. For example, coal mine collapse accidents have happened in Shanxi Province. Thus, huge loss and damages are caused to enterprises and employees. It can be said that coal mine safety production is always faced with great ordeal. Many enterprises in Chinese coal industry have not really achieved popularity of computer information system. Among coal enterprises, although computer technology has been applied, most coal enterprises just conduct preliminary exploration ad analysis and mature computer information safety system is not formed. So, computer technology cannot give play to larger functions in specific safety application. 2) Fund shortage and limited input. Exploitation of Chinese coal enterprises is chaotic. Although China has issued a large number of policy provisions and required coal enterprises enhancing safety degree in coal mining process. However, economic situations of safety production of coal enterprises do not entirely tend to be mature. Coal enterprises will often neglect the input of computer equipment in order to seek their private benefit. In view of this, China's computer information system technology is always in stagnant state. Since it is hard for facilities and equipment to reach international standard level, coal mine safety management in China is difficult to gain large production safety support.

\section{Specific application of computer information system in coal production safety management}

Firstly, check and collect computer information security. Computer information security check and collection is the process of information inspection. Computer information system needs to story safety information in computer, and automatically depict emergency safety accident handling methods. Meanwhile, concentrated check should be conducted by enterprise leaders. It is required to overall collect opinions and instructions of leaders so as to form rational potential safety hazard scheme in time. So, general inspection procedure is to first concentrate check and judgment of safety information and then implement rational safety measures according to leaders' instructions.

Secondly, carry out centralized management of shift change information. Centralized management of shift change information of coal enterprises can not just make the personnel taking their turn on duty know safety problems in the last shift, but also remind the personnel of matters needing attention in this shift. Besides, the personnel can implement accurate handling methods. In the process of duty shift, the following should be described in detail: all casualty accidents in this shift, including personal injury and property loss; the list of personnel violating enterprise rules and national relevant laws and regulations in work; prediction of production safety accident potential; work progress etc.

Thirdly, formulate coal enterprise safety system. Safety system of coal enterprises is the experience and lessons of coal mining industry from initial development to current centralized management. After many mine disasters, an increasing number of coal enterprises start to pay high attention to enterprise safety system. This is because safety system is important basis of safe mining of coal enterprises. In safety production process, corresponding system must be well implemented.

Fourthly, prevent network virus invasion. Nowadays, application of computer information system in coal enterprises has changed fixed safety production mode to a large extent. However, it also causes the danger of network virus invasion. If the computer is infected by virus, all data in the computer may be automatically deleted or revealed. This leads to great losses to the coal enterprise. To really achieve all-process and all-round monitoring of production safety information of coal enterprises, enterprises must employ professionals to carry out centralized training of employees in 
charge of production safety so as to make sure the personnel can face and hinder virus invasion calmly.

Fifthly, concentrate management of production safety accident records. After an accident happens, recorders should record the cause, process, casualty and accident handling result in the computer according to actual situations $\mathrm{p}$ form long-term data. In this way, in case of the same situation, good warning function can be reached.

Sixthly, collect all kinds of safety information and form comprehensive resorts. Coal enterprises should concentrate on collection of monthly safety information at the end of every month, and submit it to leaders in the form of monthly report for leaders' modification and audit opinion. At the end of each year, it is also required to gather monthly magazines so as to form annuals of the enterprise. In this way, coal enterprises can form good safety periodicals to warn all personnel. So, production safety management of coal enterprises is very important and can provide very important evidence for enterprise leaders to master comprehensive information and implement rational decision-making.

\section{Countermeasures to drive application of computer information system in coal production safety management}

Firstly, update leaders' concept. To establish such concept, it is required to specify that production safety information management problem belongs to a technical problem and a management problem. Only spending money cannot really implement informatization. Coal enterprises must start from actual situations and make more effects in enhancing enterprise management and implementing enterprise management innovation. On the one hand, management ability of coal enterprises should improve so as to boost quality of all employees and do basic work well of safety information management field. On the other hand, it is required to regard management innovation, technological innovation and application innovation as the subjects to construct information system of coal enterprises and achieve expected purpose.

Secondly, construct information talent team and organize information management institutions. Building a high-quality team is one of important conditions for coal enterprises to conduct informatization and implement information management system of coal enterprises. Technical workers and managers of the team should own the following qualities: correct attitude toward work; entrepreneur spirit; computer knowledge; proficient in safety production. Especially for supervisors of computer information system, they must own practical application knowledge of computer soft and hardware, system analysis capacity and system design. They should be modern inter-disciplinary talents with knowledge and ability. The establishment of computer information system is a long-term and systematic job with certain risks, it also has trans-department and multi-level features. So, information management institutions of coal enterprises should be built to take charge of coordinating information system planning, implementation and feedback etc.

Thirdly, implement computer information standardization construction. Standardization is significant basic work of coal enterprises in production safety information management and also an important link of successful information system development. Only when enterprises pay high attention to and enhance computer system standardization work can they create information system and take sustainable development way. Information standardization is the foundation of informatization. Information standardization aims to implement uniform standards for enterprise information according to relevant international standard, national standard and industrial standard. In this way, informatization form can be more standardized and trend to be standardized and systematical in information transfer. Standardization of computer information system can promote exchange and sharing. Information standardization sharing can make information own uniform standards and norms so that different computers can apply subsystem to conduct information exchange and resource sharing so as to avoid repeated data collection and input and effectively improve utilization efficiency of computer information resource.

Fourthly, pay attention to information system selection. In production safety management field, there are multiple ways for computer information system development. Generally, most coal 
enterprises are based on entrusting development, supplemented by joint development and software purchase. In this way, it is required to fully attach importance to selection of information system. Selection of computer information system should follow four principles: 1) own advancement and maturity; mature technology and product are required; 2) own openness and standard; relevant international standards, national standards and industrial norms are required; comply with standards of coal enterprises; 3) own effectiveness and sharing; it is required to master and update coal information in time and share information resources; 4) own transmissibility and safety; it is required to realize multilayered structure safety of database and ensure information system safety.

\section{Conclusions}

In conclusion, Chinese coal industry is an important support of national economic system. Production safety management problems become more prominent. To practically ensure legal rights of coal workers, better utilize rare mineral resources and improve utilization efficiency of mineral data, computer information system should be applied in production safety management, which has become an inevitable development tendency of coal management.

\section{Acknowledgments}

This paper is a college-level topic with the title of exploration of education mode of commercial vocational colleges with professional education as the core; No.: 2012yjkt04

\section{References:}

[1] Chen Liming, Application of informatization management in coal mine safety management [J]. Management \& Technology of SME, 2011 (2)

[2] Xu Yuying, On application of computer information technology in coal mine safety management [J]. China Urban Economy, 2011 (30)

[3] Zheng Baoqiang, Application of computer information system in coal mine safety management [J]. Coal Technology, 2013 (10)

[4] Li Jiashan, Yang Likun, Application of computer information technology in coal mine safety management [J]. Coal Technology, 2013 (10)

[5] Jia Hailong, Application of computer information technology in coal mine safety management [J]. Coal Technology, 2013 (12)

[6] Duan Yinku, Application of computer information technology in coal mine safety management [J]. Computer CD Software and Application, 2013 (15)

[7] Zhu Jie, Application status and development of computer technology in coal mine safety management [J]. Technology Innovation and Application, 2014 (2) 